\title{
The Various and Conflicting Notions of Information
}

\author{
Karl T. Knox \\ Nottingham Business School, Nottingham Trent University, \\ Nottingham, UK
}

karl.knox@ntu.ac.uk

\begin{abstract}
There are identified within the discourse a number of notions regarding the term information. This paper sets out to explore these sometimes-conflicting notions of information. The reason why conflicting notions occur is the result of different perspectives and understanding of the term information. Within the discourse two camps are identified, firstly, those who identify information as a resource and those who identify information as a processual approach enacted by individuals. The former is not uncommon within the business environment given the relationship seen between information and technology; this view simplifies information as merely structured data. The latter approach requires the involvement of individuals or more succinctly human understanding and interpretation. By viewing information as a processual process enacted by humans one is identifying an alternative view of how information is created, managed, used and developed. The aim is to discuss both views to gain clarity and understanding in terms of why the various and conflicting notions of information impact on its use within organisations. What is highlighted within this paper is that information is a complex and ambiguous term. There is no easy 'off-the shelf' solution to managing information. One potentially successful approach is to view information from an epistemological perspective. This requires those having to deal with this complex and ambiguous term a starting point from which to build and gain both an individual and an organisational understanding in terms of the use of information. This allows individuals to set direction, decide where to focus their effort and ultimately how to gain some control over this vital and important issue of 'information'.
\end{abstract}

\section{Introduction}

Why is it important to address this notion of information? Three main reasons, firstly within the business community the whole premise is that information technology produces something that is useful and of value i.e. information. Secondly, information is identified within a variety of disciplines, from information management through to information science and librarian studies, all of which have a relationship to information creation. Finally, the colloquial use of the term 'infor-

Material published as part of this publication, either on-line or in print, is copyrighted by the Informing Science Institute. Permission to make digital or paper copy of part or all of these works for personal or classroom use is granted without fee provided that the copies are not made or distributed for profit or commercial advantage AND that copies 1) bear this notice in full and 2) give the full citation on the first page. It is permissible to abstract these works so long as credit is given. To copy in all other cases or to republish or to post on a server or to redistribute to lists requires specific permission and payment of a fee. Contact Publisher@InformingScience.org to request redistribution permission. mation' creates confusion, given that terms are used interchangeably and mean different things to different people.

By reviewing the information systems literature and the information science literature regarding the nature of information the aim of this paper is to clarify some of the confusion and offer individuals a solid base from which they can 
develop an understanding and tackle this notion of information.

All too often when investigating information the actual focus is drawn away surreptitiously to other areas. This maybe due to the background, experience or understanding of those tasked with the investigation. Often the result is that information is neglected at the expense of other more tangible resources. Davenport (2000, p. 5) emphasises this when he acknowledges that much of what has been written historically within the information systems arena has focussed, for example on the ' $T$ ' technology in information technology at the expense of the ' $I$ ' information. This can also be said for information management, information systems and information processing.

If organisations are to seriously address the issue of creating informing systems then they must firstly address the notion of information? Dhillon (2001, p. 170) makes a strong case for investigating information within organisations when he states that information is the life-blood of the organisation. So if organisations are to fully utilise and manage their information and information systems there needs to be a focus placed on what is information, what does it mean to an organisation, how do they make use of it and what is its relationship to informing systems?

\section{Information}

Many authors identify the importance of information. Information is not necessarily a new issue, as businesses' and individuals have been dealing with information (in varies guises) for hundreds of years. This acknowledgement indicates that information does not have to be seen as computer orientated or generated, this is something that is often neglected. What is significant, in today's society, is how it has come to the forefront; due in part to the introduction and use of a number of 'information' related concepts: the information age, the information society, the information worker, information management and finally the information economy (Machlup, 1983). Given that information has come to the forefront both within the academic literature and the importance placed upon it within the business environment would seems prudent to address what the generic views of this common term 'information' seem to be.

\section{Information as a Product}

Initially and traditionally information has been seen as a structured form of data, Hall (1994, p. 283) within her research within the Scottish Textile Industry argues that information was identified as data that had been produced for subsequent use as a business resource. It is not unrealistic then to see how individuals then refer to the value of information as its ability to transform companies and increase their competitive advantage within the market place. This is because one common view of information is to view it as a tangible resource (Chaffey \& Wood, 2005; JointInformation-Systems-Committee, 1995) almost like a product which is manufactured. Other author's indicate an alternative view to information as a product when highlight the limitation of this view by stressing that information is not the same as traditional economic resources i.e. land, labour and capital; but is seen as a process enacted by individuals.

\section{Information as a Process}

The alternative view advocate by author's such as Mutch (1996), Davenport (1997) and Davenport and Prusak (1998) is to identify information as a process and signifies the role that humans make in creating information. This is clearly displayed within Boland's (1987: 377) argument when he states that information is not a resource to be stockpiled as one more factor of production.[...] It is a skilled human accomplishment. Therefore if it is not a resource but a process then how does one make sense of it?

Initially to 'get a grip' on this view one could view information in much the same way that accountants view goodwill or physical scientists view 'dark matter'. Accountants offer or place a 
value for 'goodwill' within a company's set of accounts but this is highly subjective; it can vary greatly and is often a contentious issue. Physical scientists acknowledge that 'dark matter' exists but they are unsure of where it is or how to measure it. Therefore by taking an alternative view to 'information' that is to view it, as a process that is enacted by individuals and it is these individuals who make sense, place in context and act upon the result. One is acknowledging that it is the individual through human interaction and communication that creates information and the author would suggest that the "traditional view of information as a product is in fact really referring to data and not information.

Therefore to give a precise definition is difficult as it is non visible and is created by individuals through their understanding and interpretation of data. The author would argue that 'information' is a purely human centred activity and not one that technology currently mimics. So information cannot be stockpiled, it is not 'out there' waiting to be found (a very certain philosophical interpretation) and it can mean different things to different people hence the varying and conflicting notions of information found within the business context. This then only adds to the complexity organisations encounter in trying to manage it.

\section{Review of the Product and/or Process View of Information}

So the above argument identifies two main camps those that see information as a resource or a product and those that see it as a process enacted by humans. How does this help one get to grips with it and use it for the benefit of the organisation? Initially it is important to recognise that information, in various guises is something that we have to deal with in fact Davy's (1998) view is that information is the centre of all business [public and private] and how information gets used by an organisation is the 'determining factor as to how competitive, efficient and, ultimately, profitable they are'. Interestingly, this seems quite straightforward unfortunately what is identified is a very generic definition. This generic approach is reflected in the literature so when students and researchers try to make sense of it they find themselves entering a quagmire of definition, interpretation, generality and inconsistency.

Given that we see and use the term 'information' in our everyday language one assumes that there is an almost universal acceptance of the term information; unfortunately this understanding or acceptance is more of a 'grey' mix message sense type of acceptance; in much the same way that the concept of jealousy is acknowledged but is interpreted in different ways by individuals. Therefore what then becomes paramount is the understanding and reflection upon its creation. This then impacts on its subsequent use and value within each organisation.

The emphasis placed upon the varying and conflicting notions of information are highlighted within Figure 1. The notion of information is based on examples taken from various author's writings and illustrates the many facets of this ambiguous term. The ambiguity of the term information highlights the complexity and difficulty organisations have to deal with when trying to manage their information. 


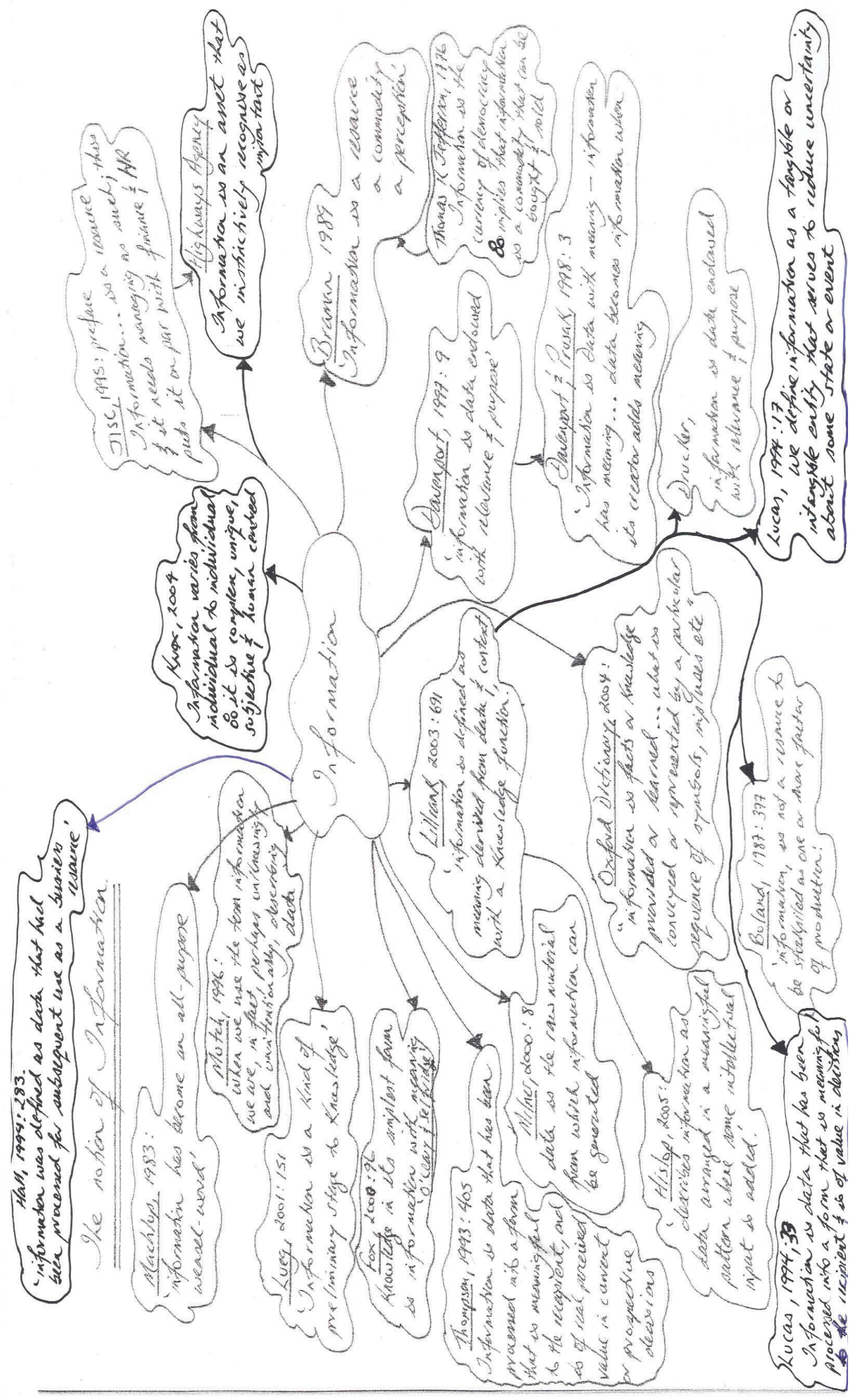

Figure 1: The Notion of Information (Knox, 2004) 


\section{How to Move Forward in Terms of Information?}

If one is to accept that there is an element of ambiguity surrounding the term information, i.e. it can mean different things to different people; it can even be created in different ways, as identified previously i.e. as a process enacted by humans. What then are individuals able to do, if one is to: see information as the by-product of a computer system; see the ubiquitous and colloquial use of the term; and the interchangeable use of terms. There are some starting points one can address within an organisation to gain an understanding of the context within which information is seen. This maybe addressed through the following questions:

- Is there a definitive definition of the term information?

- How is information created? Is information simply a 'step' in the traditional hierarchal structure of data, information and knowledge?

- How do organisations recognise what information is and how do they use it appropriately?

\section{Definitions of Information}

As seen in Figure 1 any attempt to define information categorically creates an extremely difficult and complex task. Often authors tend not to enter into the discussion as Eaton and Bawden (1991, p. 157) state we do not try to deal with the well-worked area of what is meant by information, nor do we try to distinguish between data, information, knowledge and wisdom. The result of this approach is that one can often feel as if one is 'going around in circles' a scenario where there tends to be little agreement, so no end result is reached. This lack of agreement and therefore complexity arises because the information discussion is not straightforward. Think about the following:

- How many of us would be comfortable about asking our boss or the organisation they work for to spend time investigating and trying to understand their use of and interpretation of information. It is either seen as:

- Too trivial as everyone knows what is meant by the term information and what it pertains too, or

- Simply too complex and they assimilate information with technology or systems or even data

- How many of us are able to identify what information we want, need or use

- How many of us could acknowledge that we have actually thought about what information means to us as an individual, or

- What is the information used for within the organisation and what is my role within that activity?

In reality this is not something that many managers would attempt; given the focus on 'bottom line figures, costs and return on investment strategies identified within many organisations. How would individuals cost this investigation? How would individuals show benefits, usually related to financial amounts?

A number of authors (Choo, 1998; Collins, 1997; Hislop, 2005; Knox, 2007; Mutch, 1997, 1999) would argue that there is in fact a misunderstanding and poorly discussed issue regarding the no- 
tion of what is information. Much of the problem revolves around gaining a clear workable definition of the term as well as an issue of how to use, manage and create value from information. A more conceptual definition occurs when Kroenke (2007) refers to information in the following statement information a difference that makes a difference.

What the investigator, student, researcher or organisation must realise is that they are not going to find a definitive, off the shelf, all encompassing answer to the question, What is information? There is a much bigger investigation and understanding that must take place if individuals or organisations are to benefit and get to grips with what they are trying to achieve and manage with this notion of information. The simplicity of information being seen as an international commodity $[\ldots . .$.$] and it is imperative that such a valuable resource is harnessed effectively by the business$ world as the Library \& Information Commission would have one believe (Library and Information-Commission, 1998) is in fact not necessarily appropriate or helpful in today's organisational environment. This may require an understanding of how is information created.

\section{How is information created?}

The initial questions one needs to ask and gain clarification are what is information? What does it mean to me? And how is it created?

This on the surface seems a straight forward and a sensible set of questions, given that the term information appears in our everyday language. Although because terms are used interchangeably and because of its commonality in everyday language there is an almost unspoken agreement that everyone knows what everyone else is referring too and means when they use the term information. This was so elegantly highlighted in the 'weapons of mass destruction' debate that preceded the Iraq War. Unfortunately as one will identify within the following discussions there is much confusion within a simple term. Not making explicitly clear what one means can lead to drastic consequences.

Wilson (1986) supports this complexity by arguing that the common usage of the term is a problem. Wilson (1986, p. 12) states when we look more closely at the nature of information, that everyday certainty about its character disappears. That is, this everyday use of the term and commonality creates much of the ambiguity and confusion. Checkland and Howell (1998, p. xii) concur with Wilson when they highlight that much of the literature within information systems exhibits $a$ confusion between basic concepts of data, information and knowledge and more importantly the relationship between them. This suggests that they are different or are they one in the same i.e. a semantic issue. E.g. the author could argue that historically one would be involved in data management, data processing or data analysis, subsequently this progressed or was rebranded as information management and is now seen within the remit of knowledge management. Lueg (2001, p. 151) argues that information is a kind of preliminary stage to knowledge. This, to some extent, clearly identifies one reason why a hierarchical structure of the terms has been forthcoming within the literature.

\section{Data, Information and Knowledge - The Hierarchical Structure of Information Creation}

Further reasons for the creation of the hierarchical structure or relationship is seen by Drucker (cited in Clark, 1997) who reinforces this as he suggests that information is a pre-requisite of knowledge, this is also acknowledge by Marchand (2000, p. 3) who argues that information is the way people in business express, represent, communicate, and share their knowledge highlighting this tenuous relationship between information and knowledge. Drucker $(1999$, p. 124) refers to information as data endowed with relevance and purpose, therefore bringing in data as a prerequi- 
site for information and further enhancing the equation that data + information $=$ knowledge $\mathbf{O R}$ data + information + knowledge $=$ wisdom.

Therefore, what is data? Marchand (2000, p. 4) argues that data exists all around us in the form of signals, events and situations. Within the context of the Data Protection Act 1984, which responds to the need for protection of privacy, defines data as information recorded in a form that can be processed by equipment operating automatically in response to instructions given for that purpose. This equates data with information, which the author would suggest is a common misconception within the information systems discourse. The problem is akin to one mans terrorist is another mans freedom fighter, just as one mans data is another mans information. Therefore, is information just data that is placed into a meaningful context? But then what becomes 'a meaningful context'; in just the same way as levels of jealously are different for individuals.

Fox $(2004$, p. 96) argues that data are stored in many formats and encoded using increasingly sophisticated conventions and standards. Knowledge, in its simplest form, is information with meaning (O'Leary \& Selfridge, 2000). Davenport (1997, p. 3) moves this discussion further along by stating that information and knowledge are quintessentially human creations, and we will never be good at managing them unless we give people a primary role. Something the author would concur with but again there seems to be linkages between the various terms without a real discussion as to what each one of them pertains to. But Davenport's inclusion and realisation of the individuals' part in the creation of information is paramount to gaining a better understanding of this elusive term information.

\section{An Explanation of this Conflation (Hierarchy) of Data, Information and Knowledge}

There seems, within the current literature, an almost robotic relationship between data, information and knowledge, as referred to in the previous paragraphs.

That is, one leads to the next as identified by Davenport $(1997$, p. 9$)$ that data are simple observations of states of the world, information is data endowed with relevance and purpose, and knowledge is valuable information. Sveiby $(1997$, p. 42) identifies that information is meaningless, but becomes meaningful knowledge when it is interpreted. The question would be who or what offers this interpetation - humans, of course. Spek and Spijkervet (1997) state that data are understood to be symbols that have not yet been interpreted, information is data with meaning, and knowledge is what enables people to assign meaning and thereby generate information. They bring in the human element but assume that one level leads to the next level. English (1999) views the relationship between data and information as follows: Information is data in context. Information is usable data. Information is the meaning of data, so facts become understandable. This is again identified by Chaffey and Wood (2005, p. 21) when they identify knowledge as being the combination of data and information to which is added expert opinion, skills and experience to result in a valuable asset which can be sued to make decisions.

Checkland and Holwell (1998, p. 86) categorically state that data and information are different by arguing that making sense of the field of IS requires a very clear concept of what information is; they then further this by acknowledging there seems to be a very confused state within the IS field arguing that there is at present no well-defined definition of such terms as 'data' and 'information' upon which there is general agreement. Does this imply that this hierarchical view of data, information and knowledge is not as clear as many authors are suggesting?

The fundamental notion of all of these definitions or interpretations above is that we do something to data to produce information and subsequently do something to information to eventually create knowledge. This then suggests that data is a prerequisite for information, and information is a prerequisite for knowledge. Thereby creating what is traditionally seen as a hierarchical 
structure between data, information and knowledge (Figure 2) without really questioning what each one is or how each one relates to the others or in fact how each one is created.

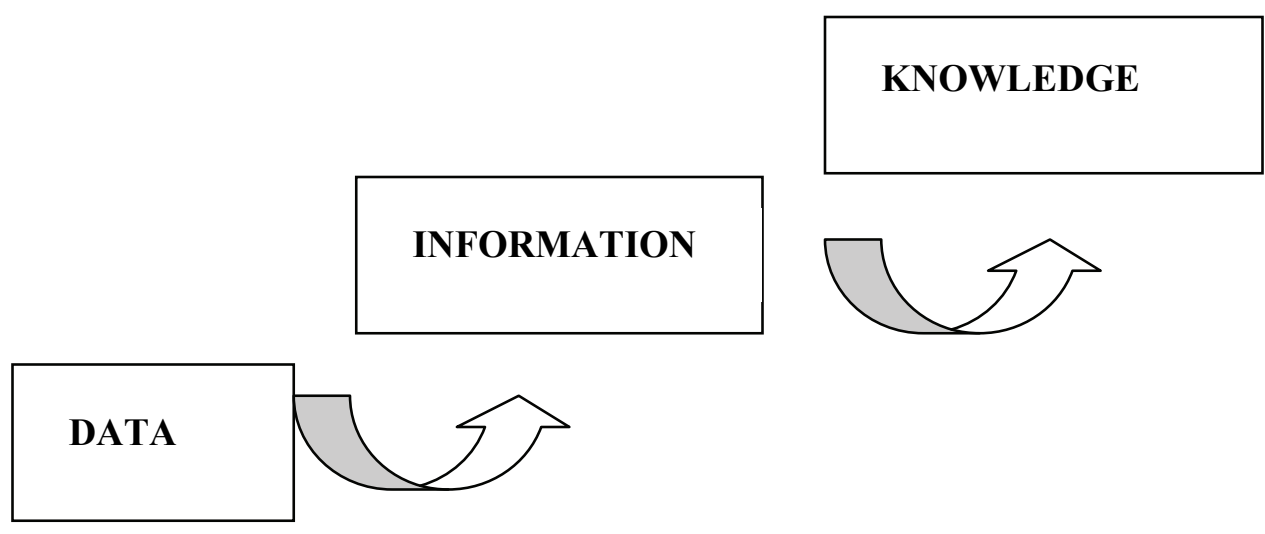

Figure 2: the hierarchical nature of information

This approach suggests that data is the building block of information and that information then somehow generates knowledge. I.e. data are seen as simple facts that can be structured into information, this in turn becomes knowledge when it is interpreted and put into context, or when meaning or value are added; but by whom or by what? And does this also suggest that anyone can generate knowledge by building on information?

The problem, the author feels, is that the majority of discussions within the field of data, information or knowledge assumes that there is a common understanding of the terms or concepts being discussed; that there is a hierarchical relationship, that this discussion is one directional and that by going through the stages knowledge will be generated; this is in fact not the case

This ambiguity in relation to the use of the terms, data, information and knowledge are highlighted in Table 1.

Within Table 1, many varied interpretations are evident. What is apparent is the almost sacrosanct hierarchical nature of data, information and knowledge. Most do not acknowledge that each stage can generate others from it i.e. knowledge can generate data. In fact what is often neglected is the dynamic interaction between all elements. The author would suggest that it is easy to follow the upward version of data supporting the generation of information, which in turn creates knowledge but this does not question how each are created, or interpreted within the various situations therefore there is little commonality; also very few acknowledge that knowledge in turn can be a creator of data and information (see Figure 3) therefore highlighting the interaction of all elements and the fluidity of the hierarchy. Even more important is the impact that ones perception of what constitutes data, information and knowledge (i.e. ones epistemological perspective) will impact on ones view of what is data, information and knowledge in relation to the environment i.e. how individuals interpret data, information and knowledge will impact on what course of action they will undertake in collecting, managing and sharing these within their organisation. 
Table 1: Data, Information, Knowledge Distinction

\begin{tabular}{|c|c|c|c|}
\hline Author & Data & Information & Knowledge \\
\hline $\begin{array}{l}\text { Davies \& Ledington } \\
\text { (1991) p4 }\end{array}$ & $\begin{array}{l}\text { Data consists of many } \\
\text { individual bits/pieces/items } \\
\text { or facts that can be simul- } \\
\text { taneously, or sequentially, } \\
\text { processed to support the } \\
\text { learning process }\end{array}$ & $\begin{array}{l}\text { Information is not some } \\
\text { object that exists in the } \\
\text { world - information is part } \\
\text { of the learning process - } \\
\text { information has meaning } \\
\text { according to the interpreta- } \\
\text { tion which is happening }\end{array}$ & $\begin{array}{l}\text { No actual reference to the } \\
\text { term knowledge }\end{array}$ \\
\hline Drucker (1989) p46 & $\begin{array}{l}\text { Data is relatively easy to } \\
\text { capture and does not nec- } \\
\text { essarily require analysis }\end{array}$ & $\begin{array}{l}\text { Information is data en- } \\
\text { dowed with relevance and } \\
\text { purpose }\end{array}$ & $\begin{array}{l}\text { Knowledge, by definition, } \\
\text { is specialised }\end{array}$ \\
\hline $\begin{array}{l}\text { Checkland \& Holwell } \\
\text { (1998) p88, }\end{array}$ & $\begin{array}{l}\text { Data are checkable facts, } \\
\text { that can be agreed, dis- } \\
\text { puted both of which allow } \\
\text { supporting evidence to be } \\
\text { brought forward }\end{array}$ & $\begin{array}{l}\text { This is data - capta that } \\
\text { then has been enriched. } \\
\text { i.e. related to other things, } \\
\text { seen as part of a larger } \\
\text { whole - gains significance }\end{array}$ & $\begin{array}{l}\text { Larger structures of re- } \\
\text { lated information - ex- } \\
\text { pected to have longevity }\end{array}$ \\
\hline $\begin{array}{l}\text { Chaffey \& Wood } \\
(2005, \text { p21) }\end{array}$ & $\begin{array}{l}\text { Decrete, objective facts } \\
\text { about events. Data are } \\
\text { transformed into informa- } \\
\text { tion by adding value } \\
\text { through context, categori- } \\
\text { sation, calculations, correc- } \\
\text { tions, and condensation }\end{array}$ & $\begin{array}{l}\text { Organised data, meaningful } \\
\text { and contextually relevant. } \\
\text { Used for decision making }\end{array}$ & $\begin{array}{l}\text { The combination of data } \\
\text { and information to which } \\
\text { is added expert opinion, } \\
\text { skills and experience to } \\
\text { result in a valuable asset } \\
\text { which can be used to } \\
\text { make decisions }\end{array}$ \\
\hline $\begin{array}{l}\text { Boddy, Boonstra and } \\
\text { Kenndy (2002, p6, 15) } \\
\text { Citing Martin et al, } \\
1994 \text {, Turban, et al, } \\
1999 \text { \& }\end{array}$ & $\begin{array}{l}\text { Refers to recorded descrip- } \\
\text { tions of things, events, } \\
\text { activities and transactions }\end{array}$ & $\begin{array}{l}\text { Information is data that has } \\
\text { been processed so that it } \\
\text { has meaning and value to } \\
\text { the recipient }\end{array}$ & $\begin{array}{l}\text { No clear definition is } \\
\text { offered except to state } \\
\text { certain information sys- } \\
\text { tems help people to make } \\
\text { decisions by incorporat- } \\
\text { ing human knowledge } \\
\text { into the system }\end{array}$ \\
\hline $\begin{array}{l}\text { Hislop (2005) p13, } 14 \\
15 \text { \& } 16\end{array}$ & $\begin{array}{l}\text { One could see data as be- } \\
\text { ing raw numbers, facts, } \\
\text { images, words, sounds } \\
\text { based on observation or } \\
\text { measurment }\end{array}$ & $\begin{array}{l}\text { Information represents data } \\
\text { arranged in a meaningful } \\
\text { pattern, data where some } \\
\text { intellectual input has been } \\
\text { added }\end{array}$ & $\begin{array}{l}\text { Means to analyse / under- } \\
\text { stand information / data, } \\
\text { belief about causality of } \\
\text { events / actions, and pro- } \\
\text { vides the basis to guide } \\
\text { meaningful action and } \\
\text { thought. That is one could } \\
\text { say knowledge can be } \\
\text { understood to emerge } \\
\text { from the application, } \\
\text { analysis and productive } \\
\text { use of data and/or infor- } \\
\text { mation }\end{array}$ \\
\hline Davenport (1997) p9 & $\begin{array}{l}\text { Simple observations of the } \\
\text { states of the world } \\
\text { - easily structured } \\
\text { - easily captured on ma- } \\
\text { chines } \\
\text { - often quantified } \\
\text { - easily transferred }\end{array}$ & $\begin{array}{l}\text { Data endowed with rele- } \\
\text { vance and purpose } \\
\text { - requires some unit of } \\
\text { analysis } \\
\text { - need consensus on mean- } \\
\text { ing } \\
\text { - human mediation neces- } \\
\text { sary } \\
\text {-people turn data into in- } \\
\text { formation }\end{array}$ & $\begin{array}{l}\text { Valuable information } \\
\text { from the human mind, } \\
\text { includes reflection, syn- } \\
\text { thesis, context } \\
\text { - hard to structure } \\
\text { - difficult to capture on } \\
\text { machines } \\
\text { - often tacit } \\
\text { - hard to transfer }\end{array}$ \\
\hline
\end{tabular}


What all of these views neglect to really get to grips with is circularity of the terms and the impact that the human element (Ledington (1991) does address this in the 'learning process') has on each. The circularity element indicates the bi-directional relationship between the elements. The human centred element indicates their ability to ascribe meaning, interpretation and understanding. This draws questions about the individuals' philosophical view of the world - something that in terms of information is not generally focussed upon. This limited view is acknowledged by Davenport and Prusak (1998: 2) where they identify that data is a set of discrete, objective facts about events...data describes only a part of what happened; it provides no judgement or interpretation that makes a difference...unlike data, information has meaning...data becomes information when its creator adds meaning. It is this human element i.e. the individuals understanding, and use that is so important and often not recognised as part of the problem of information generation together with the inter-relatedness of the elements that has generated an alternative model to the traditional hierarchical view of data, information and knowledge; seen in Figure 3.

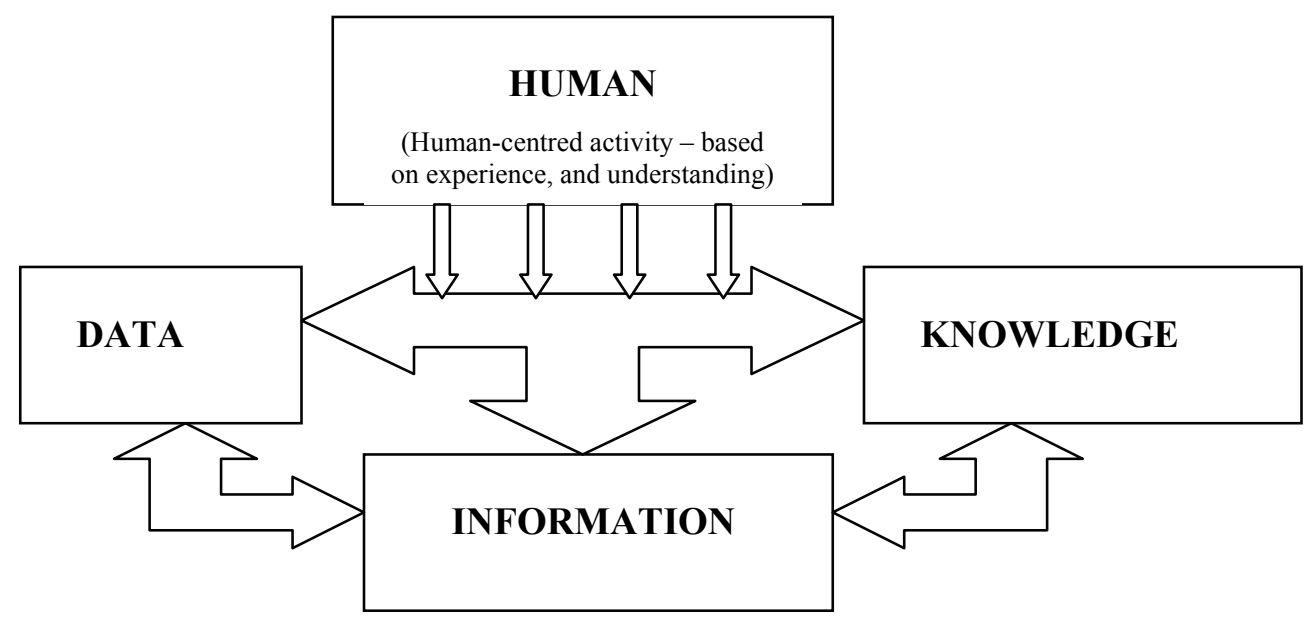

Figure 3: The Dynamic (and circular) Relationship between data, information, knowledge and humans (Knox, 2007)

Therefore what can be said about the hierarchical structure of data, information and knowledge? The terms themselves are nebulous and invariably used interchangeably.

Davies and Ledington (1991, p. 2) argue information is often assumed to be the same as data. It is not. Datum from the Latin dare, meaning to give may seem similar to a general interpretation of information but it is not. The author would concur with Davies and Ledington (1991) to acknowledge that information is more than data and requires some form of human interaction in the form of interpretation. This element of interpretation signifies that an individual or a group of individuals are starting to make sense of something and use their uniquely human attributes to then make decisions from this. By questioning this traditional hierarchical view blind acceptance is removed and even raises alternatives as identified by Tuomi (2000) who argues that there is a reverse hierarchy of data - information and knowledge as data emerges last - only after knowledge and information are available. This turns the traditional hierarchal structure around and questions ones view and understandings by arguing that data is a result of having information and that information emerges only after one already has knowledge i.e. data does not exist in isolation but is a result of human intervention by creating data via their knowledge and understanding. This supports the alternative model seen in Figure 3 and raises the philosophical debate to which we now turn. 


\section{Philosophical Issues of Information}

The author would argue that one approach, mentioned briefly at the start of the paper, is to view information from an epistemological perspective. That is, as Lincoln and Guba (1994, p. 108) identify as the epistemological question - what is the nature of the relationship between the knower and the would-be knower and what can be known? Hirschheim et al (1995, p. 20) denotes the term epistemology as the nature of human knowledge and understanding that can possible be acquired through different types of inquiry and alternative methods of investigation. What the author is suggesting is that students, researchers and organisations when investigating the notion of information need to consider how they view the world and therefore what information means to them in light of their view of the world. As the author identifies and argues that how one views the world (i.e. the student, the researcher and the organisation) and subsequently what one sees as being valid and acceptable knowledge has a profound influence on the perceived relative importance of how they in-turn address the issue of information. This is not necessarily the place for a full-blown discussion on philosophy or philosophical issues. What needs to be identified, initially, is that how one views the world can fall into a number of ontological interpretations. Ontology Wand and Weber (1993, p. 220) identify ontology to be a branch of philosophy concerned with articulating the nature and structure of the world. Crotty (1998, p. 10) identifies that ontology is concerned with 'what is', with the nature of existence, with the structure of reality.

Therefore by taking different ontological views of the world and coupling them with relevant epistemological views of the world one is able to identify how this in tern impacts on what individuals, and organisations can relate to as information.

Table 2: Ontological and epistemological views in relation to information (Knox, 2007)

\begin{tabular}{|c|c|c|}
\hline $\begin{array}{l}\text { Ontological } \\
\text { Perspectives }\end{array}$ & $\begin{array}{c}\text { Interpretation - in terms of informa- } \\
\text { tion }\end{array}$ & $\begin{array}{l}\text { Epistemological Perspec- } \\
\text { tives }\end{array}$ \\
\hline $\begin{array}{l}\text { Realism } \\
\text { The notion that the } \\
\text { world exists out- } \\
\text { side of the mind }\end{array}$ & $\begin{array}{l}\text { Therefore information is a tangible object just } \\
\text { waiting to be found, and can be discovered } \\
\text { through objectivist approaches }\end{array}$ & $\begin{array}{l}\text { Objectivism } \\
\text { Meaningful reality exists as } \\
\text { such apart from the operation of } \\
\text { any consciousness, i.e. it is there } \\
\text { waiting to be discovered }\end{array}$ \\
\hline $\begin{array}{l}\text { Idealism } \\
\text { The notion that } \\
\text { world exists only } \\
\text { within the mind }\end{array}$ & $\begin{array}{l}\text { The concept of information is imposed - this } \\
\text { maybe based on dreams, beliefs, understand- } \\
\text { ing - that is meaning comes from anything but } \\
\text { the interaction between subject and the object } \\
\text { - one is imposing meaning on the object }\end{array}$ & $\begin{array}{l}\text { Subjectivism } \\
\text { Meaning is imposed on the ob- } \\
\text { ject by the subject - i.e. from } \\
\text { lls thoughts - beliefs }\end{array}$ \\
\hline Critical Rea & $\begin{array}{l}\text { The notion that truth, meaning and therefore } \\
\text { information comes into existence through the } \\
\text { our engagement with the realities in our world } \\
\text { Le actors, humans, structures etc. }\end{array}$ & $\begin{array}{l}\text { Constructionism } \\
\text { Therefore meaning is not dis- } \\
\text { covered as in objectivism but is } \\
\text { dolonstructed through interaction. }\end{array}$ \\
\hline
\end{tabular}

Where issues arise is in the confusion between what is ontological and what is epistemological. Ontological is the structure of the world and epistemological is concerned with deciding what 
kinds of knowledge are possible, therefore valid, possible and appropriate within that world. Obviously how one thinks knowledge is create impacts on how one goes about collecting it, managing etc - this where the author is identifying the importance of understanding the epistemological view of information and one that seems to be missing in much of the investigate and literature to date which concern information, information systems and informing systems. This relationship and confusion is also seen within the research methods field (Knox 2004).

What one can identify from Table $\mathbf{2}$ is what one identifies as being legitimate knowledge is impacted on how one views the world. This in turn has a bearing on how one view's information and therefore how one goes about collecting it, managing it and disseminating it via the concept of an informing system.

\section{Example:}

If one takes a definition on offer in Figure 1 i.e. JISC - 1995 - information is a resource and its needs managing as such; this puts it on par with finance and human resource management. There is an obvious assumption that 'information' is viewed in a very economic way, that is, it is just like the traditional economic resources of land, labour and capital. If information is taken in this way one would suggest that information is an object; that it is factual and independent of anything else i.e. it exists out side of the mind (a realist ontology) and that meaning resides within that object (an objectivist epistemology) and therefore only information that is quantifiable through objectivist techniques is valid and trustworthy, hence appropriate methods for collecting and managing that information are valid. This, however, implies that information is tangible, visible and therefore quantifiable. This is not what some others authors, from Figure 1 would argue. Boland (1987, p. 377) for one argues that information is not a resource to be stockpiled as one or more factor of production. It is meaning and can only be achieved through dialogue in a human community. Information is not a commodity. It is a skilled human accomplishment. Boland takes the approach that information and meaning is therefore constructed between interaction of both subject and object, this would imply an epistemological approach to knowledge and leaves no direction as to the ontological view but it could easily be that of realism.

This discussion between ontology and epistemology can be looked at in more depth at a later stage, it is enough to recognise, at this stage, that there are strong grounds for questioning ones notion of what is information. Interestingly Tuomi (2000) highlights the difficult in taking this epistemological approach by stating that the existence of thorny epistemological issues is recognised but not discussed, and references to relevant literature outside the cognitivistic tradition are rarely made explicit.

It is interesting to note that if one takes the notion of information to be a commodity as Barford (1997) suggests that information has become such a thing, it is then easy to appreciate and understand why so much investment in information technology in terms of time, money and effort has been see within the business world. If organisations accept the importance of information and view it as a resource one can identify with the effort to find the 'holy grail' that of information, and knowledge management through technology - unfortunately this belief that technology can create and deliver the appropriate information when needed is based on a flawed epistemological approach.

\section{Conclusions}

What can be identified from this investigation into the various and conflicting notions of information are:

- there is no 'off the shelf answer to what is information 
- the notion of information and the nature of information are themselves elusive and open to a great deal of interpretation

- investigating how information is created focuses on the epistemological aspect of information and therefore what is seen as valid information within the organisation

- this in turn focuses organisations in terms of where to invest in terms of information technology

- where to focus training i.e. in terms of individual needs within the organisation, how and where to development individual skill though to how to structure their data, how to value and use information in the most competitive manner for their organisation

- data, information and knowledge are not separate entities there is a dynamic and circular interaction between them which places the human element at the centre. Knowledge can generate new data and this is a recurring process

- By understanding information better organisations and individuals are better placed to develop systems that meet their needs and therefore support the overall aims and objectives of the organisation.

\section{References}

Barford, J. A. (1997). Balance or Bias? Information selection for the researcher. Internet Research: Electronic Networking Applications and Policy, 7(1), 53-58.

Boddy, D., Boonstra, A. \& Kennedy, G. (2002). Managing information systems: An organisational perspective. Harlow, Pearson Education Limited.

Boland, R. J. (1987). The in-formation of information systems. Critical Issues in Information Systems, pp: 377.

Chaffey, D. \& Wood, S. (2005). Business information management: Improving performance using information systems. Harlow, Prentice Hall, Pearson Education Limited.

Checkland, P. \& Holwell, S. (1998). Information, systems and information systems: Making sense of the field. Chicester, John Wiley \& Sons Ltd.

Choo, C. W. (1998). The knowing organisation: How organisations use information to construct meaning. New York, Oxford University Press.

Clark, A. (1997). Being there. Cambridge, MA: MIT Press.

Collins, D. (1997). Knowledge work or working knowledge? Ambiguity and confusion in the analysis of the 'knowledge age'. Employee Relations, 19(1), 38 - 50.

Crotty, M. (1998). The foundations of social research: Meaning and perspective in the research process. London: Sage Publications.

Davenport, T. H. (1997). Information ecology. Oxford: Oxford University Press.

Davenport, T. H. (2000). Putting the I in IT. In D. A. Marchand, T. H. Davenport, \&T. Dickson, Mastering Information Management. London: Prentice Hall.

Davenport, T. H. \& Prusak, L. (1998). Working knowledge: How organisations manage what they know. Boston: Harvard Business School Press.

Davies, L. \& Ledington, P. (1991). Information in action. London: MacMillan Press.

Davy, K. (1998). Information strategy and the modern utility - Building competitive advantage. London: Financial Times Publishing. 
Denzin, N. K. \& Lincoln, Y. S. (Eds.). (1994). Handbook of qualitative research. London: Sage Publications.

Dhillon, J. K. (2001). Challenges and strategies for improving the quality of information in a university setting: a case study. Total Quality Management, 12(2), 167-177.

Drucker, P. F. (1988). The coming of the new organisation. Harvard Business Review, 66(January - February), pp:45 - 53.

Drucker, P. F. (1989). The new realities. Heinemann.

Drucker, P. F. (1999). Management challenges for the twenty-first century. Oxford, UK: ButterworthHeinemann.

Eaton, J. \& Bawden, D. (1991). "What kind of resource is information?" International Journal of Information Management, 11(2), 156-165.

English, L. (1999). Improving data warehouse and business information quality. Methods for reducing costs and increasing profits. New York, Wiley.

Fox, R. (2004). Moving from data to information: OCLC systems \& services. International Digital Library Perspectives, 20(3), 96-101.

Hall, H. (1994). Information strategy and manufacturing industry - Case studies in the Scottish textile industry. International Journal of Information Management, 14, 281 - 294.

Hirschheim, R., Klein, H. K., \& Lyytinen, K. (1995). Information systems development and data modelling. Cambridge, U.K.: Cambridge University Press.

Hislop, D. (2005). Knowledge management in organisations: A critical introduction. Oxford: Oxford University Press.

Joint-Information-Systems-Committee, (1995). Information strategy - An executive briefing. JISC Publication.

Knox, K. T. (2004). A researcher's dilemma - Philosophical and methodological pluralism. Electronic Journal of Business Research Methods, 2(2), 119 - 128. Available at http://www.ejbrm.com/vol2issue2/vol2-issue-art7.htm

Knox, K. T. (2007). An investigation into the information strategy formulation process within a higher education institution: A case study approach. Nottingham Business School. Nottingham, Nottingham Trent University: 256 .

Kroenke, D. M. (2007). Using MIS. Upper Saddle River, New Jersey: Pearson, Prentice Hall.

Library and Information-Commission. (1998). 2020 Vision. London: The Commission.

Lueg, C. (2001). Information, knowledge and networked minds. Journal of Knowledge Management, 5(2), 151-159.

Machlup, F. (1983). Semantic quirks in studies of information. In F. Machlup \& U. Mansfield, The study of information: Interdisciplinary messages. New York: Wiley.

Marchand, D. A. (2000). Competing with information: A manager's guide to creating business value with information content. Chichester: John Wiley and Sons.

Martin, E. W., DeHayes, D. W., Hoffer, J. A. \& Perkins, W. C. (1994). Managing information technology; What managers need to know. New York: Macmillan.

Mutch, A. (1996). No such thing as information resource management. Management Decision, 34(7), 58 62.

Mutch, A. (1997). Information literacy: An exploration. International Journal of Information Management, $17(5), 377-386$. 
Mutch, A. (1999). Critical realism, managers and information. British Journal of Management, 10, 323 333.

O'Leary, D. E. \& Selfridge, P. (2000). Knowledge management for best practice. Communications of the $A C M, 43(11), \mathrm{pp}: 12-24$.

Spek, R. v. d. \& Spijkervet, A. (1997). Knowledge management: Dealing intelligently with knowledge. CIBIT, Ultrecht: Kenniscentrum.

Sveiby, K. E. (1997). The new organisational wealth: Managing and measuring knowledge-base assets. San Francisco: Berret-Koehler.

Tuomi, I. (2000). Data is more than knowledge: Implications of the reversed knowledge hierarchy for knowledge management and organisational memory. Journal of Management Information Systems, 16(3), 103 - 117.

Wand, Y. \& Weber, R. (1993). On the ontological expressiveness of information systems analysis and design grammars. Journal of Information Systems, 3(4), 217 - 237.

Wilson, T. D. (1986). Information needs in social services. Research highlights in Social Work, 13, $12-24$. Retrieved from http://information.net/tdw/pub1/papers/infoneeds85.html

\section{Biography}

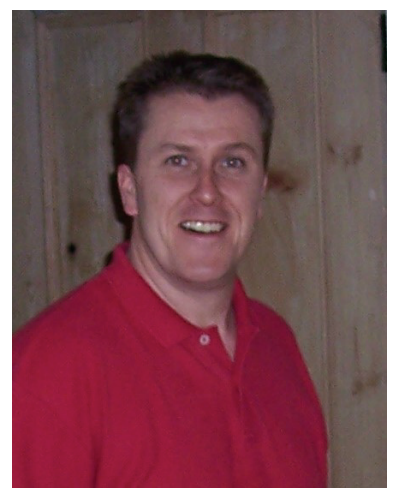

Karl T. Knox is a Senior Lecturer in Information Management, Nottingham Trent University, Nottingham Business School, Department of Information Management \& Systems. Prior to joining NTU, Karl has worked at a number of universities gaining a wide variety of experience both culturally and academically. Karl has been on staff at The Robert Gordon University, in Aberdeen, Scotland, Leeds Metropolitan University, Dubai Polytechnic, U.A.E and Southern Cross University, in Australia. His industrial experience has been gain in a variety of five star establishments' world wide, including: Inter Continental Hotels, Hilton International Hotels, The Dorchester Hotel and The Laneborough Hotel. He holds a MSc in Information Management from Lancaster University, a PGCE in Business Studies and Economics from the University of London, Institute of Education and a BA (Hons) in Accountancy and Economics from The City of London Polytechnic. His research interests are in the field of information management and information strategy and the process of information strategy development within organisations. 